\title{
Organizational Effectiveness in Helping Affected Communities Covid-19
}

\author{
Bambang Widodo ${ }^{1, *}$ Muzayanah ${ }^{1}$ Totok Suyanto ${ }^{2}$ Eko Budiyanto ${ }^{1}$ Nugroho Purnomo ${ }^{1}$ \\ ${ }^{1}$ Department of Geography Education, Faculty of Social Sciences and Law, Universitas Negeri Surabaya, Surabaya, \\ Jawa Timur, 60231, Indonesia \\ ${ }^{2}$ Department of Civic Education, Faculty of Social Sciences and Law, Universitas Negeri Surabaya, Surabaya, Jawa \\ Timur, 60231, Indonesia \\ *Corresponding author. Email: bambangsigit@unesa.ac.id
}

\begin{abstract}
This research is based on field facts related to the Covid-19 pandemic that has hit Indonesia. Apart from the health side, the impacts are also economic and social. The high unemployment due to layoffs in the formal sector and the loss of informal sector jobs must be seriously addressed by the government and related institutions. Universitas Negeri Surabaya are among the government institutions that must have a role in helping people affected by Covid-19, especially in East Java. Universitas Negeri Surabaya role in helping people affected by Covid-19 in East Java must be seen from the effectiveness of its performance so that accountability can be accounted for in the community. This type of research is quantitative with a survey approach. The research subjects or samples were the community, students, paramedics who were affected by Covid-19 and received assistance from Universitas Negeri Surabaya, as well as the Unesa Crisis Center team and Unesa stakeholders as program owners. The number of research samples was 103 respondents. Instruments for collecting research data were divided into 2 types: firstly, instruments for affected communities, and secondly, instruments for program implementers. The form is in the form of a questionnaire, google form, interview and documentation. The results of the questionnaire and google form will be used as data to perform a descriptive percentage analysis. The results showed that the role of Universitas Negeri Surabaya in helping people affected by Covid-19 in East Java was categorized as very high or above $75 \%$. The effectiveness can be seen from the categories: program planning, evaluation, involvement of human resources, community feedback and input, accuracy of targeting program recipients, and its benefits.
\end{abstract}

\section{Keywords: Analysis, Organizational effectiveness, Covid-19 affected communities}

\section{INTRODUCTION}

The development of Covid-19 has not yet subsided. Approximately 28.8 million people worldwide are infected with this disease. The virus that causes COVID-19 is mainly transmitted through the droplets that are produced when an infected person coughs, sneezes, or exhales. These droplets are too heavy and cannot stay in the air, so they quickly fall off and stick to floors or other surfaces. The graph of the development of people who are infected every day in Indonesia continues to increase. As of September 2020, the number of people infected with covid-19 in the world was 33.8 million, 1.01 million died and 23.5 million people were declared cured. In Indonesia, there were 287 thousand infected with Covid-19 until September 2020, 10,740 thousand died, and 215 thousand were declared cured. Whereas in East Java in the same month, data were obtained from people infected with Covid-19 totaling 43,744, died 3,192, and 37,058 were declared cured. The following is a chart between April September 2020.

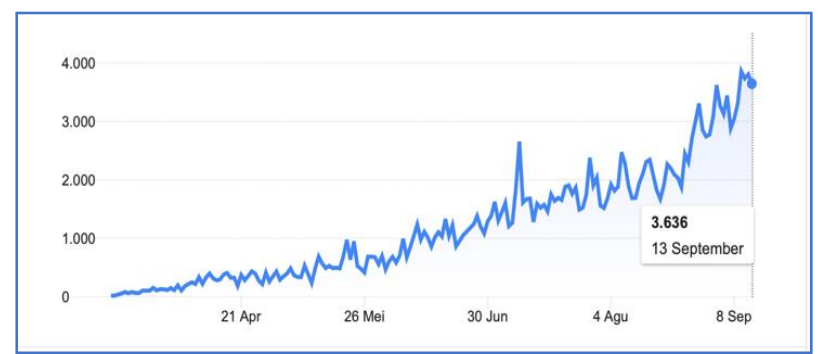

Figure 1 Data on the number of people infected covid-19

Source: taskforce covid-19 center

Covid-19 actually does not only have an impact on the health aspects alone, but on other aspects, namely economic and social. The purpose of social distancing is to reduce the likelihood of contact between an infected 
person and another person who is not infected, so as to minimize transmission of disease, for example, such as closing schools, workplaces, isolation, quarantine, closing or restricting public transportation. As a result, many companies have laid off employees, and daily workers or freelancers have lost their jobs.

The formal sector workers who were dismissed until April 2020 have reached 1.24 million, while approximately 256 thousand informal workers have been affected by Covid-19. Meanwhile, the Indonesian Center of Reform on Economics (CORE) estimates that the number of open unemployment in the second quarter of 2020 will increase by 4.25 million people. This figure is a projection made by CORE based on a mild scenario for the impact of the corona pandemic. Meanwhile, in the medium scenario, there will be an additional 6.68 million unemployed people, while in the severe scenario there will be 9.35 million people.

The government has taken anticipatory steps to overcome the unemployment problem caused by covid- 19 . Social assistance programs and village fund allocations to cover the needs of people affected by Covid-19 are national priority programs. Refocusing and reallocation of funds to government agencies and SOEs are intended to accelerate the response to the Covid-19 pandemic, including universities. Universitas Negeri Surabaya (Unesa) is one of the state universities that is also involved in the response to covid-19 in East Java. This is in line with what [1] notes that societies around the world are gradually coming to terms with the understanding that we all have to behave responsibly and change our less responsible behaviors in dealing with certain issues which affect mankind regardless of whether we live in an advanced or the less advanced part of the world. Idowu explained that social responsibility has now undergone a change where the world community has changed its understanding of being a responsible person and changed behavior that is less responsible in helping to overcome certain problems, both in developed and developing countries. Policy implementation is certainly based on transparency and accountability, so that Unesa as part of the government must be able to demonstrate its credibility and responsibility effectively and efficiently. According to [2] the concept of accountability, together with the institutions through which the concept is articulated and implemented, is perhaps the single most important factor that controls holders of political and public administrative power. He has observed, "Accountability is at the heart of governance within democratic societies". From this statement it is clear that accountability is at the core of governance with a democratic society. Based on the above background, this study aims to see the effectiveness of
Unesa's role in helping people affected by Covid-19, especially in East Java.

This research basically has the following objectives: 1). To find out Unesa's strategic policies and programs in helping people affected by Covid-19 in East Java, especially in supporting the concept of modern management that is transparent and accountable in order to realize clean government and good governance, 2 ). To find out whether Unesa is effective or not in helping people affected by Covid-19 in East Java, from a transparent and accountable modern management point of view in order to realize clean government and good governance.

\section{METHOD}

\subsection{Types and Research Approaches}

This study aims to determine the effectiveness of Unesa's role in helping communities affected by Covid-19 in East Java. This type of research is quantitative with a survey approach. Research surveys are developed as a form of positivistic approach to the social sciences. As stated by Groves [3] "surveys produce information that is statistically in nature". Survey is the basic form of quantitative ". Survey research asks several respondents about their beliefs, opinions, characteristics, and behaviors that have occurred or are currently happening. The survey provides questions for research on self-reported beliefs / beliefs or behaviors. These questions become sharper when the respondent provides answers to questions with the desired variables. Kerlinger [4] explains that survey research is a study that examines large and small populations (universe) by selecting and examining the selected sample from that population, to find the relative incidence, distribution and interrelation of the variables.

\subsection{Population and Sample}

The population is the whole research subject, while the sample is a part or representative of the population. The population in this study were all people who received assistance from Unesa's assistance program through the Unesa Crisis Center (UCC). The determination of the sample in this study was carried out by means of purposive sampling, where the sampling was based on special considerations, namely: the population sampled in this study were those who had knowledge of Unesa's assistance, consisting of community groups, students, paramedics, the UCC team and related stakeholders. The number of samples in this study were 103 people who would later become respondents, divided into the following clusters. 
Table 1. Distribution of research respondent

\begin{tabular}{|c|c|c|}
\hline Respondent & Amount & Data Information \\
\hline $\begin{array}{l}\text { Communities affected } \\
\text { by covid-19 and } \\
\text { recipients of assistance } \\
\text { from the Unesa Crisi } \\
\text { Center (UCC) }\end{array}$ & 47 & $\begin{array}{l}\text { Respondents } \\
\text { provide data and } \\
\text { information related } \\
\text { to unesa } \\
\text { assistance } \\
\text { (instrument 1). }\end{array}$ \\
\hline $\begin{array}{ll}\text { Students } & \text { receiving aid } \\
\text { from UCC } & \text { and other } \\
\text { Unesa } & \text { assistance } \\
\text { programs } & \end{array}$ & 36 & $\begin{array}{l}\text { Respondents } \\
\text { provide data and } \\
\text { information related } \\
\text { to unesa } \\
\text { assistance } \\
\text { (instrument 1). }\end{array}$ \\
\hline $\begin{array}{l}\text { Medical personnel who } \\
\text { receive assistance from } \\
\text { UCC }\end{array}$ & 13 & $\begin{array}{l}\text { Respondents } \\
\text { provide data and } \\
\text { information related } \\
\text { to unesa } \\
\text { assistance } \\
\text { (instrument 1). }\end{array}$ \\
\hline UCC team & 4 & $\begin{array}{l}\text { Respondents } \\
\text { provide data and } \\
\text { information related } \\
\text { to program } \\
\text { planning } \\
\text { (instrument 2) }\end{array}$ \\
\hline $\begin{array}{l}\text { Unesa } \\
\text { management }\end{array}$ & 3 & $\begin{array}{l}\text { Respondents } \\
\text { provide data and } \\
\text { information related } \\
\text { to program } \\
\text { planning } \\
\text { (instrument 2) }\end{array}$ \\
\hline
\end{tabular}

\subsection{Research Variables}

Variable is something that becomes the object of research observation, often referred to as a factor that plays a role in the research or the symptoms to be studied. According to Kerlinger (2006) variables are constructs or properties to be studied that have varying values. The determination of the variables in this study was based on indicators from the work program compiled by the Unesa Crisis Center, then the researchers used them as research variables. The variables in this study can be explained in the following table.

Table 2. Research Variables

\begin{tabular}{|c|l|}
\hline Variables & \multicolumn{1}{|c|}{ Variables Indicators } \\
\hline \multirow{3}{*}{ Strategic programs } & 1. Program planning \\
\cline { 2 - 2 } & 2. Program implementing \\
\cline { 2 - 2 } & 3. Program evaluating \\
\hline \multirow{2}{*}{ Human resources } & 1 . Competences \\
\cline { 2 - 2 } & 2. Qualified \\
\hline \multirow{2}{*}{ Funding } & 1. Budgeting system \\
\cline { 2 - 2 } & 2. Supervision system \\
\hline \multirow{3}{*}{ Stakeholders Perception } & 1. Knowledge \\
\cline { 2 - 2 } & 2. Information \\
\cline { 2 - 2 } & 3. Response \\
\hline
\end{tabular}

\subsection{Data Collection Techniques}

Data collection was carried out in 2 ways. First, it is done directly by distributing questionnaires to respondents, and second, indirectly through google form. The second method of collecting data is based on the consideration that the respondents have sufficient knowledge of the internet, especially students and paramedics. In addition, researchers dig up information to triangulate data by interviewing several related parties and knowing Unesa's assistance program for people affected by Covid-19 in East Java. These informants include: structural officials, program implementers, program recipients (students, staff, lecturers, and the community).

\subsection{Research Instruments}

The form of the instruments in this study were: 1) google form for some respondents who can access via the internet, 2) questionnaires that are filled in directly by respondents in the field, and 3) Interview guidelines for informants as a form of data triangulation

\subsection{Data Analysis}

To find out the general response of research respondents related to Unesa's assistance, descriptive statistics were used through percentages. The data from the questionnaire in this study is quantitative data, which will be analyzed descriptively in percentage with the steps according to Ridwan [5] as follows: 1) calculating the value of the respondent and each aspect or sub variable, 2) Recap values, 3) calculate the average value, and 4) calculate percentage.

\section{RESULT AND DISCUSSION}

\subsection{Result of The Research}

\subsubsection{Respondent characteristics}

Respondents who were sampled in this study can be explained based on 2 categories, namely: the category of beneficiaries / programs, and the category of program implementers / stakeholders. For the characteristics of respondents receiving assistance from 167 questionnaires (google form) that were distributed, 103 respondents filled in the data, and of these respondents who stated that they received assistance as much as $95.1 \%$ as shown below.

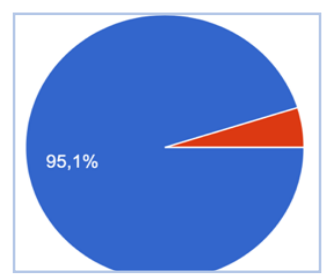


Figure 1 Respondent receiving assistance.

The results also showed that the frequency of respondents who received assistance varied greatly from the never before to more than 4 times. However, the largest data for aid recipients were 1 times as much as $40.8 \%$, then 2 times as much as $33 \%$ and more than 4 times as much as $14.6 \%$ as shown in the list of figures below.

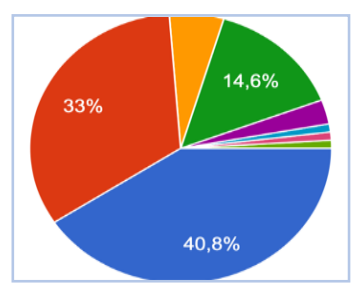

Figure 2 The frequency of respondents who received assistance

Seen from a gender perspective, the recipients of assistance from Unesa were $64.1 \%$ male and $35.9 \%$ female, as shown in the figure below.

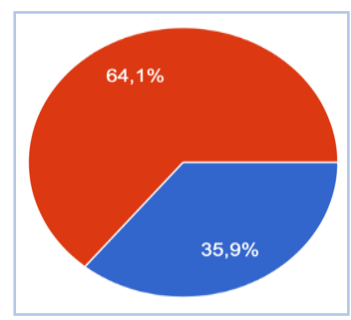

Figure 3 Gender perspective

\subsubsection{Aid effectiveness}

The effectiveness of aid is seen from 2 aspects, namely: a) assistance according to needs, and b) assistance can overcome urgent problems. Aid recipient respondents gave an assessment that the assistance provided by Unesa had a very positive preference. Regarding whether the assistance is in accordance with the respondent's needs, $58.3 \%$ said it was appropriate, and $32 \%$ said it was appropriate. In this context it can be concluded that the recipients of the aid in the very high category trusted Unesa. Meanwhile, those who said it was not suitable were 6 people or $5.8 \%$, and those who said it was not suitable were only 1 person or $1 \%$, and those who wanted it in the form of money were only $1 \%$. More details related to the respondent's opinion can be seen in the image below.

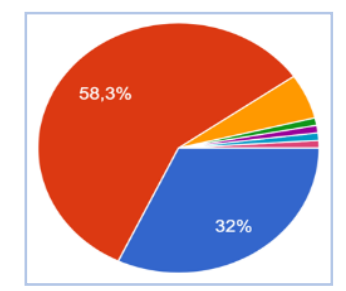

Figure 4 Assistance according to needs

Unesa's assistance if it was associated with benefits in overcoming problems, got very positive results, namely $58.3 \%$ stated that they could be useful in overcoming problems, and $28.2 \%$ said that they were very able to solve problems. Meanwhile, those who stated that they could not and could not were still in the very low category, namely $6.8 \%$ and $3.9 \%$. Furthermore, it can be seen in the image below.

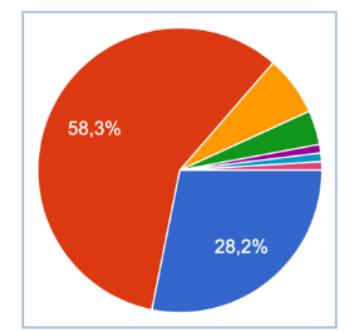

Figure 5 Assistance for urgent problems

\subsubsection{Program Planning}

The results of the study can explain that the planning of the Unesa assistance program for people affected by Covid-19 in East Java is in the very good category where $66 \%$ of the responses say often and $20 \%$ say always, only $13.3 \%$ say sometimes. The data is in accordance with the results of an interview with one of the informants who said the following. "Even though we don't often meet physically, we continue to coordinate, especially in terms of planning assistance programs, because requests keep coming, if not coordinated, it's very prone to deviation, please check with other friends". Furthermore, it can be seen in the image below.

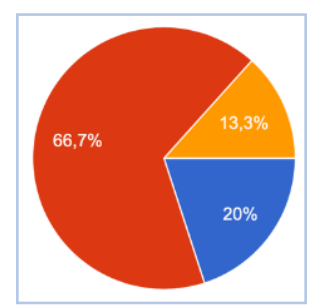

Figure 6 Program Planning 


\subsubsection{Involvement of human resources in decision making}

Based on the results of the study, it shows that the involvement of personnel in making decisions for handling Covid-19 is $20 \%$ said they were always involved, $33.3 \%$ said they were often involved and $33.3 \%$ said they sometimes. The rest, about $13 \%$ said that they never did and didn't know. Based on these data it can be concluded that the involvement of personnel in the high category is above $50 \%$. The following is an overview of the data.

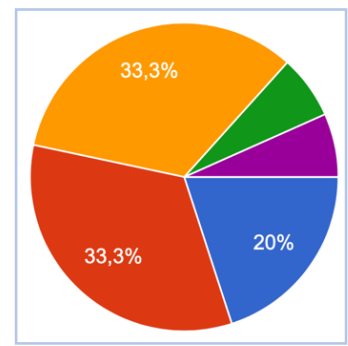

Figure 7 Involvement of human resources in decision making

\subsection{Discussion}

Communities affected by covid-19 are individuals or groups of individuals who are directly or indirectly affected by the covid-19 pandemic, both health impacts and economic and social impacts. The government also officially designated the corona virus (Covid-19) outbreak as a National Disaster through Presidential Decree Number 12 of 2020 concerning the Determination of Non-Natural Disaster for the Spread of covid-19 as a National Disaster. In a disaster situation, the government is mandated by the constitution to be able to guarantee the safety or survival of its people in the midst of a disaster. The role of government agencies to help people affected by covid- 19 must be balanced with behavior that adheres to health protocols. Awareness of using masks, keeping your distance, and using hand sanitizers are preventive steps to prevent the spread of covid-19. The results of research conducted by Sun [6] on 5,761 respondents in china about the awareness of using masks when going to the hospital were $96.9 \%$. The results of this study also concluded that education for the public about the awareness of using masks is an important part of preventing the transmission of covid-19. The same opinion was expressed by Manfred [7] who said that the use of masks was the most effective way to fight covid19. Research that has been carried out on students in schools that experience lock down, after the opening and students are allowed to go to school, many are found in schools that do not obey using masks, so the new covid19 cluster has increased significantly, and finally lock down action is carried out again.

Thus, to prevent the increase and spread of Covid-19 requires awareness from all parties. Such awareness must be created from a positive frame of mind, an honest heart and the right actions. The role is an important part of any organization to realize its concern for the covid-19 disease outbreak.

While the definition of role is a series of behaviors expected from a person based on social position, both formally and informally. There are also those who say that the meaning of this role is an action carried out by an individual or group of people in an event or event, and is a form of behavior expected of someone who has a position in society.

According to Soekanto [8] what is meant by role is a job that is carried out dynamically according to the status or position that is carried. The status and position are in accordance with social order, even in the order of action, they are all adapted to different roles. Meanwhile, Riyadi [8] defines the role as an orientation or concept that is formed due to a party in social opposition in people's lives. It is based on the individual and also the reasons for taking the desired action. Another opinion put forward by Thoha [9] that role is a series of a person's behavior that is carried out based on his character. This condition can be motivated by a person's psychology in carrying out the desired action, according to his conscience. the role referred to here is the role of universities, and in this case is Unesa.

According to Benneworth [10], universities are a means to mobilize social activities which consist of various and interrelated elements. The role of higher education is to provide public services related to information, social relations, as well as the dissemination of academic findings, so as to create critical power. According to Benneworth [10] its most significant, where engagement provides a means of rooting the university in its host society, the termination of that engagement would completely change the nature of the institution: providing information, public relations, dissemination of academic findings, university as a cultural influence, critical engagement.

Transparency and public accountability are one of the pillars of good governance. The existence of transparency in government administration and policy making can be an entry point for the public to obtain information so that they can check and balance the running of government. Accountability is a form of responsibility of a person (leader, officer or executive) or an organization to parties who have the right or authority to request information related to performance or actions in carrying out the mission and objectives of the organization in the form of 
periodically determined reports. According to UNDP (United Nations Development Program), accountability is an evaluation of the process of implementing activities / organizational performance so that it can be accounted for and as feedback for organizational leaders to be able to further improve organizational performance in the future. Accountability in order to create clean government to build healthy institutions / organizations must be based on social values [11].

\section{CONCLUSION}

The effectiveness of Universitas Negeri Surabaya as part of a government institution in helping people affected by Covid-19 in East Java is in the very effective category. The effectiveness of the above $75 \%$ of respondents strongly agree and agree. The effectiveness is seen from the aspects: accuracy of aid programs, program implementation starting from planning, implementation and evaluation, as well as the benefit of the assistance program for the community. What is still lacking is feedback from the community for Universitas Negeri Surabaya.

\section{ACKNOWLEDGMENT}

Thank you to the Rector of the Universitas Negeri Surabaya, the head of LPPM Unesa and all of researchers member who have worked hard to obtain research data in the covid-19 pandemic situation.

\section{REFERENCES}

[1] Samuel O. Idowu • Claus Strue Frederiksen • Asli Yuksel Mermod - Morten Ebe Juul Nielsen, Corporate Social Responsibility and Governance: Theory and Practice. London: Springer International Publishing, 2015.
[2] M. Schacter, How Good is Your Government. Washington DC: The World Bank, 2008.

[3] R. M. Groves, R. B. Cialdini, and M. P. Couper, "Understanding the decision to participate in a survey," Public Opin. Q., 1992, doi: $10.1086 / 269338$.

[4] F. N. Kerlinger and H. B. Lee, "The Foundation of Behavioural Research," in Foundation of Behavioral Research, 2009.

[5] Riduwan, The Basics of Statistics. Bandung: Alphabeta, 2018.

[6] C. X. Sun et al., "Public Awareness and Mask Usage during the COVID-19 Epidemic: A Survey by China CDC New Media," Biomed. Environ. Sci., vol. 33, no. 8, pp. 639-645, 2020, doi: $10.3967 /$ bes2020.085.

[7] M. Spitzer, "Masked education? The benefits and burdens of wearing face masks in schools during the current Corona pandemic," Trends Neurosci. Educ., vol. 20, no. June, p. 100138, 2020, doi: 10.1016/j.tine.2020.100138.

[8] Riyadi, Regional Development Planning: Controlling Strategy Potential in Realizing Regional Autonomy. jakarta: Gramedia, 2002.

[9] Mi. Thoha, Organizational Behavior: Basic Concepts and Applications. jakarta: Rhineka Cipta, 2002.

[10] Paul Benneworth, University Engagement with Socially Excluded Communities. Dordrecht: Springer Science+Business Media, 2013.

[11] and M. W. Kevin Keasey, Steve Thompson, Corporate Governance: Accountability, Enterprise and International Comparisons. London: John Wiley \& Sons Ltd, 2005. 